\title{
PENINGKATAN PRESTASI DAN PROSES BELAJAR KIMIA DASAR MAHASISWA BILINGUAL MELALUI STRATEGI TEAM-BASED LEARNING
}

\author{
Sri Rahayu \\ FMIPA Universitas Negeri Malang \\ email: srirahayu_um@hotmail.com
}

\begin{abstract}
Abstrak: Penelitian tindakan kelas ini bertujuan untuk mendeskripsikan prestasi belajar, kualitas proses pembelajaran dan persepsi mahasiswa terhadap penerapan strategi Team-Based Learning. Subjek penelitian adalah mahasiswa Program Studi Pendidikan Kimia Bilingual FMIPA UM yang menempuh matakuliah Kimia Dasar I pada Tahun Akademik 2012/2013. Penelitian tindakan kelas dengan tiga siklus ini meliputi langkah-langkah perencanaan, implementasi tindakan, observasi, dan refleksi. Instrumen penelitian adalah tes prestasi belajar, catatan lapangan, pedoman observasi dan angket. Data dianalisis secara kuantitatif dan kualitatif. Hasil penelitian menunjukkan bahwa setelah mengikuti perkuliahan: (1) prestasi belajar mahasiswa meningkat dan hampir 100\% mahasiswa mencapai skor 70; (2) kualitas proses pembelajaran meningkat, semakin banyak kelompok dapat menyelesaikan tugas tepat waktu, interaksi antar mahasiswa dan kemampuan dalam presentasi berbahasa Inggris meningkat; (3) mahasiswa memiliki persepsi positif terhadap pembelajaran.
\end{abstract}

Kata Kunci : team-based learning, prestasi belajar, proses belajar, persepsi, kimia dasar

\section{INPROVEMENT ON THE CHEMISTRY ACHIEVEMENT AND THE LEARNING PROCESS OF UNIVERSITY BILINGUAL STUDENTS THROUGH TEAM-BASED LEARNING STRATEGY}

\begin{abstract}
This classroom action research aims to describe students' achievement, the quality of the learning process and students' perception on the implementation of the Team-Based Learning strategy. The subjects were bilingual students of the Chemistry Education Program of FMIPA UM who took a course of Basic Chemistry I in the academic year of 2012/2013. The three-cycle action research included the steps of planning, implementation of action, observation, and reflection._The research instruments were an achievement test, field notes, observation sheets and questionnaires. The data were analyzed quantitatively and qualitatively. The results show that after the students attended the instruction: (1) their achievement increased and nearly 100\% of the students achieved a score of 70; (2) the quality of the learning process improved, more and more groups could accomplish the assignments on time, the interaction among students and the ability to present in English also improved; (3) students had positive perception towards the strategy.
\end{abstract}

Keywords: team-based learning, learning achievement, learning process, basic chemistry

\section{PENDAHULUAN}

Sudah menjadi gambaran umum bahwa dosen di Perguruan Tinggi menyampaikan materi perkuliahan yang diampu kepada mahasiswa kebanyakan melalui ceramah. Hal ini tampak juga dalam kegiatan belajar mengajar di Jurusan Kimia Universitas Negeri Malang (UM), khususnya pada matakuliah Kimia Dasar I dan II. Selain memberikan ceramah, dosen memberi tugas terstruktur untuk memperkuat konsep ma- hasiswa dan mendesain tes untuk mengukur penguasaan mahasiswa terhadap konsep yang telah dipelajarinya. Mahasiswa bekerja secara individual dalam menyelesaikan tugas dan kegiatan kerja sama tidak diharapkan bahkan dilarang. Penggunaan metode ceramah yang terusmenerus tanpa variasi metode lain akan mendorong mahasiswa sebagai pembelajar yang pasif dan lingkungan belajar menjadi kompetitif dan kurang interaktif. 
Sebagai mata kuliah kimia yang pertama kali ditempuh mahasiswa, Kimia Dasar merupakan mata kuliah yang sangat strategis karena merupakan landasan untuk mengikuti mata kuliah kimia lanjut ataupun mata kuliah lain nonkimia. Dengan demikian, jika mahasiswa gagal dalam menempuh mata kuliah ini, dapat diprediksikan akan gagal dalam mengikuti mata kuliah kimia lanjut. Hal tersebut dapat dipahami karena struktur dari ilmu kimia adalah berjenjang sehingga untuk menguasai suatu topik harus menguasai konsep prasyaratnya (Gabel, 1999).

Sejak tahun 2009 Jurusan Kimia FMIPA UM menyediakan 4 offering Kimia Dasar regular dan 1 offering Kimia Dasar SBI (Bilingual). Untuk pembelajaran Kimia Dasar I bilingual, digunakan handouts dan media berbahasa Inggris, sedangkan penyampaian materinya dilakukan secara verbal dalam bahasa Inggris yang diselingi bahasa Indonesia. Mahasiswa yang mengambil offering ini diseleksi hanya berdasarkan skor TOEFL institusional dan nilai TOEFL itu umumnya berkisar antara 389-496 (dokumen Jurusan Kimia, 2010) dengan kemampuan akademik yang bervariasi. Prestasi belajar ratarata mahasiswa yang menempuh Kimia Dasar I bilingual semester I tahun 2010/2011 tergolong kurang, yaitu sebesar 59 dan hanya 33\% mahasiswa yang dapat memperoleh skor 70 atau nilai B (Dokumen Jurusan Kimia, 2010). Tampaknya, kurangnya hasil belajar mahasiswa ini karena kemampuan bahasa Inggris yang terbatas sehingga kesulitan untuk membaca handouts dan buku teks berbahasa Inggris. Selain itu, mahasiswa masih perlu belajar beradaptasi dengan situasi belajar di perguruan tinggi yang sangat berbeda dengan situasi belajar di sekolah.

Oleh karena rendahnya tingkat pemahaman mahasiswa bilingual terhadap Kimia, Kimia Dasar dirasakan sebagai pelajaran yang sulit bagi sebagian besar mahasiswa. Dalam belajar kimia banyak sekali tuntutan yang harus dipenuhi baik oleh pengajar maupun mahasiswa dan seringkali tuntutan ini tidak dapat diatasi (Stieff \& Wilensky, 2003). Misalnya, agar kimia dapat dipahami dengan baik maka mahasiswa harus menguasai tiga aspek kimia, yaitu (1) makroskopis yang berkaitan dengan fenomena yang dapat diamati; (2) submikroskopis yang terkait dengan partikel; dan (3) simbolik, yang menggambarkan materi dengan rumus kimia dan persamaan reaksi (Johnstone, 2000). Selain karena kompleksitas struktur keilmuan dari kimia itu sendiri yang menyebabkan kimia sulit (Gabel, 1999), lingkungan/atmosfer belajar (termasuk penggunaan strategi ceramah yang digunakan satu-satunya di kelas) dan penggunaan bahasa Inggris sebagai bahasa pengantar untuk membaca literatur dan berkomunikasi juga menjadi permasalahan tersendiri. Oleh karena itu, terlihat mendesak untuk memecahkan permasalahan ini.

Salah satu cara memecahkan masalah di atas adalah dengan menerapkan strategi pembelajaran yang inovatif. Dalam literatur disebutkan bahwa mengubah tanggung jawab belajar pada diri mahasiswa melalui penerapan pendekatan active learning akan menghasilkan keuntungan yang signifikan. Salah satu strategi pembelajaran berorientasi active larning adalah team-based learning (TBL). Slavin (1995) dan Turner (2001) menggambarkan TBL sebagai cara yang layak untuk meningkatkan kinerja belajar dalam seting pendidikan. Berbagai hasil penelitian menunjukkan bahwa penggunaan tim belajar dapat meningkatkan hasil belajar, mendorong perkembangan ketrampilan berfikir kritis, meningkatkan rasa percaya diri, memberikan konteks pada relevansi bidang studi, menetapkan kepemilikan hasil belajar, mendorong interaksi dalam kelompok, dan menyiapkan mahasiswa untuk dapat bekerja di masa mendatang (Johnson \& Johnson, 1986).

Keefektivan TBL sebagai strategi pembelajaran berdasarkan fakta bahwa strategi tersebut mengasah berkembangnya kelompok pada tingkat kekompakan (kohesivitas) yang tinggi, yang pada gilirannya akan menghasilkan berbagai hasil belajar yang positif. Hal ini jelas akan membutuhkan proses transformasi untuk mengembangkan kelompok-kelompok belajar yang kecil menjadi tim belajar yang kompak/ kohesif dan tangguh. Sebagai salah satu kelompok belajar yang kecil, TBL memiliki langkah pembelajaran yang unik yaitu diawali dari perhatian terhadap individu, kemudian kelompok 
dan pemberian umpan balik langsung sehingga memudahkan dan mendorong mahasiswa untuk terlibat penuh dalam materi perkuliahan. Khususnya, TBL menciptakan lingkungan belajar di mana siswa dapat memenuhi kebutuhannya untuk terlibat dalam proses negosiasi dan penguasaan materi perkuliahan bersama teman sekelasnya (Sweet \& Pelton-Sweet, 2008: 30).

TBL merupakan strategi pembelajaran yang relatif baru dan semakin banyak dipergunakan di perguruan tinggi seperti dalam pendidikan medis atau pendidikan bisnis. Strategi pembelajaran TBL lebih berpusat pada siswa, namun strategi ini dapat mendorong penerapan pengetahuan dengan menggunakan kelompokkelompok kecil, Strategi ini dapat meningkatkan keterlibatan siswa, mendorong pembelajaran aktif dan dirasakan menyenangkan bagi siswa (Tan dkk, 2011).

Sweet \& Michaelsen (2007) mengemukakan bahwa TBL merupakan salah satu bentuk belajar kolaboratif (collaborative learning) yang khusus. Strategi ini terdiri dari tiga fase yang berulang-ulang. Fase pertama adalah aktivitas di mana mahasiswa diminta untuk membaca dan mempelajari bahan ajar secara mandiri sebelum masuk kelas. Pada fase kedua, mahasiswa mengerjakan pretest secara individu untuk mengetahui pemahaman mereka terhadap fakta atau konsep yang terdapat dalam bahan ajar yang telah diberikan pada fase 1 dantes ini disebut uji jaminan kesiapan (individual readiness assurance test (IRAT)). Setelah menyelesaikan IRAT, tim belajar yang telah dibentuk sebelumnya yang terdiri dari 5-7 orang mahasiswa mengerjakan tes yang sama dan kemudian membuat kesepakatan mengenai jawaban setiap soal yang diujikan pada fase kedua. Tes ini disebut group readiness assurance test (GRAT). Kesepakatan jawaban yang telah dibuat oleh kelompok dalam tes langsung diberi skor agar dapat segera diberi umpan balik.

Ketika pengajar sudah merasa bahwa mahasiswa telah menguasai konsep dasar melalui fase 1 dan 2, kelas beralih ke fase ketiga, yaitu aktivitas penerapan. Selama fase 3, siswa bekerja dalam timnya untuk menyelesaikan tugasnya, yaitu menerapkan pengetahuan yang diperoleh pada fase 1 dan 2 dalam masalah-masalah kompleks yang ada di alam semesta. Semua tim di kelas mengerjakan masalah yang sama pada saat yang bersamaan. Tim berbagi jawabannya tentang soal-soal aplikasi secara serentak dengan segera membandingkan jawaban mereka dengan jawaban tim lainnya. Karena masalah mencerminkan kompleksitas alam semesta dan ambigu, maka mahasiswa akan menghasilkan pemecahannya yang bermacam-macam. Hal ini akan mendorong terjadinya diskusi kelas. Sebagai bagian dari proses, mahasiswa juga menilai kontribusi anggota timnya/teman sebaya dalam kelompok mereka (evaluasi peer).

Selain menyampaikan materi dan aktivitas di kelas, TBL juga mendorong partisipasi aktif mahasiswa untuk mempersiapkan diri sebelum masuk kelas dan diskusi kelas. Oleh karena itu, waktu di kelas berubah dari belajar fakta menuju pada aplikasi dan integrasi informasi. Tidak seperti beberapa model pembelajaran aktif lainnya seperti PBL, pengajar TBL tetap mengontrol materi dan dosen bertindak sebagai fasilitator sekaligus ahli materi(Thompson, dkk. 2007).

Michaelsen \& Sweet (2008:8) mengemukakan bahwa keberhasilan dalam menerapkan pembelajaran dengan TBL ditentukan oleh empat unsur dasar: (1) kelompok, yaitu kelompok harus dibentuk dan diatur secara memadai; (2) akuntabilitas, yaitu mahasiswa diberi tanggung jawab baik secara individu maupun kelompok; (3) umpan balik, yaitu mahasiswa diberi umpan balik secara terus menerus dan pada saat yang tepat; serta (4) desain tugas, yaitu tugas-tugas kelompok harus mendorong belajar mahasiswa dan perkembangan kelompok.

Beberapa hasil penelitian menunjukkan bahwa: (1) TBL lebih efektif dalam meningkatkan prestasi belajar dibandingkan dengan perkuliahan dengan ceramah (Letassy, dkk, 2008); (2) TBL dapat meningkatkan rasa percaya diri (self-efficacy) mahasiswa (Macke \& Tapp, 2012) dan; (3) penerapan TBL dirasakan penting oleh mahasiwa di enam universitas di Bangkok dan mereka menyukai strategi pembelajaran ini (Thanongsak, Kalayanee, \& Raveewan, 2011). 
Penggunaan TBL dalam pembelajaran dapat menciptakan lingkungan belajar yang mendorong interaksi mahasiswa, dapat meningkatkan prestasi belajar dan keterampilan berpikir tingkat tinggi serta meningkatkan rasa percaya diri mahasiswa. Oleh karena itu, strategi ini dirasakan sesuai untuk diterapkan dalam meningkatkan kualitas perkuliahan Kimia Dasar I bilingual.

Adapun hipotesis tindakan yang dikemukakan adalah: "Implementasi strategi pembelajaran TBL dapat meningkatkan kualitas proses dan hasil pembelajaran Kimia Dasar I pada mahasiswa bilingual Tahun Pertama di jurusan kimia FMIPA Universitas Negeri Malang".

\section{METODE}

Penelitian ini menggunakan rancangan penelitian tindakan kelas (classroom action research) yang digambarkan sebagai sebuah siklus yang terdiri dari perencanaan, tindakan, observasi, dan refleksi (Kemmis \& McTaggart, 1988). Siklus ini akan terulang lagi sehingga membentuk sebuah spiral self-reflektif seperti tampak dalam Gambar 1.

Penelitian ini menerapkan tiga siklus yang dilakukan selama bulan Agustus - Desember 2012. Dalam setiap siklus dilakukan pembelajaran dengan strategi pembelajaran Team-
Based Learning (TBL). Berikut ini langkahlangkah yang telah dilakukan dalam penelitian:

\section{Tahap Diagnostik}

Dalam tahap diagnostik dilakukan kegiatan (1) mengumpulkan data prestasi belajar dan proses belajar mengajar di kelas saat ini serta informasi tentang latar belakang pendidikan seperti prestasi belajar mahasiswa ketika di SMA dan skor TOEFL; (2) menganalisis data-data yang diperoleh dan merumuskan permasalahan; (3) mengidentifikasi strategi pembelajaran yang cocok dengan permasalahan dan merumuskan hipotesis tindakan.

\section{Tahap Perencanaan}

Kegiatan yang dilakukan dalam tahap perencanaan: (1) membuat rencana pembelajaran dengan strategi $T B L$, membuat instrumen pretest \& posttest dengan pilihan ganda untuk setiap pokok bahasan dan handouts; (2) menyiapkan lembar observasi dan angket semi terstruktur dan terbuka untuk menjaring persepsi mahasiswa terhadap strategi yang diimplementasikan, dan jurnal dosen; (3) mengatur kelompok mahasiswa yang heterogen berdasarkan jenis kelamin, prestasi belajar di SMA dan nilai TOEFL. Kelompok heterogennya sebanyak 6 (enam) yang masing-masing jumlahnya 3-4 mahasiswa.

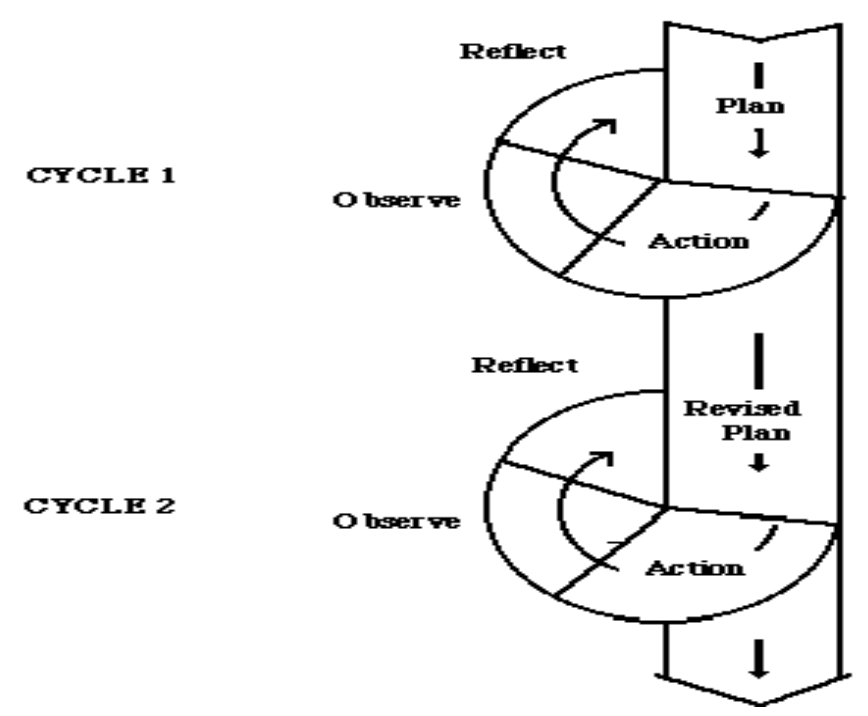

Gambar 1. Spiral Self-Reflektif (Kemmis \& McTaggart, 1988)

\section{Tahap Tindakan}


Dalam tahap tindakan, kegiatan yang dilakukan adalah menerapkan langkah-langkah pembelajaran TBL sebagai berikut.

- Preparation. Mahasiswa diberi handouts untuk dibaca di rumah atau di luar kelas sebelum memulai pertemuan pertama pada pokok bahasan tertentu.

- Readiness Assurance. Pada fase ini mahasiswa secara individual diberi pretest yang berbentuk pilihan ganda, kemudian tes yang sama diberikan lagi kepada masing-masing kelompok untuk dikerjakan bersama. Setelah itu kelompok memberikan argumentasi tentang jawaban mereka dan kemudian diberi umpan balik oleh dosen dan didiskusikan di kelas.

- Concept Application. Mahasiswa diberi aktivitas yang berorientasi pada penerapan konsep. Mahasiswa mendiskusikan tugasnya dalam timnya.

- Memberikan posttest tentang materi yang baru dipelajari. Posttest ini diberikan di setiap akhir siklus penelitian.

- Meminta mahasiswa untuk menilai sumbangan setiap anggota kepada timnya.

\section{Tahap Observasi}

Dalam tahap observasi, kegiatan yang dilakukan adalah (1) mengisi lembar pengamatan proses belajar mengajar dan membuat catatan dalam jurnal jika ada hal-hal istimewa terjadi selama proses pembelajaran sambil membantu mahasiswa bekerja dalam kelompoknya; (2) mengumpulkan data pretest individu di setiap awal pokok bahasan, memberikan tes prestasi belajar (posttest) dan angket di akhir setiap siklus PTK.

\section{Tahap Refleksi}

Data yang diperoleh pada tahap observasi selanjutnya diorganisasi, dianalisis, dan disimpulkan sebagai hasil penelitian. Refleksi dilakukan setelah mengkaji hasil penelitian untuk selanjutnya digunakan sebagai pertimbangan dalam membuat rencana revisi (pada siklus ke-2). Tahap-tahap penelitian perencanaan, tindakan, observasi dan refleksi ini akan terulang kembali pada siklus ke-2 dan ke-3.
Subjek penelitian adalah mahasiswa tahun pertama Program Studi Pendidikan Kimia Bilingual yang menempuh matakuliah Kimia Dasar I sebanyak 23 mahasiswa dan lokasi penelitian di Jurusan Kimia FMIPA Universitas Negeri Malang. Mahasiswa mendapatkan perkuliahan tatap muka dilakukan 2 kali pertemuan perminggu (@100 menit per pertemuan).

Instrumen pengumpul data berupa jurnal dosen, lembar observasi aktivitas mahasiswa, angket tentang persepsi mahasiswa tentang pembelajaran dan tes prestasi belajar yang mengukur pemahaman konsep mahasiswa dalam pokok bahasan sebelum dan sesudah pembelajaran, yaitu dalam pokok bahasan: Measurement, Matter and Its' Changes, dan Nomenclature inorganic chemistry and quantitative composition of compound.

Data penelitian berupa catatan dalam jurnal dosen dan lembar observasi, pernyataan dalam angket, dan skor prestasi belajar yang ditunjukkan oleh skor dalam posttest dan pretest. Data dianalisis secara kualitatif dan kuantitatif. Analisis kualitatif dilakukan untuk mengetahui kualitas proses pembelajaran dari data observasi aktivitas mahasiswa, jurnal dosen dan angket. Analisis kuantitatif dilakukan untuk mengetahui prestasi belajar mahasiswa ditinjau dari skor rata-rata pretest dan posttest mahasiswa terhadap materi pelajaran. Peningkatan prestasi belajar dilihat dengan cara membandingkan skor pretest dan posttest yang diperoleh di setiap siklus. Tingkat penguasaan materi mahasiswa ditunjukkan oleh seberapa besar pemahaman mahasiswa terhadap materi pelajaran. Penguasaan materi mahasiswa dilihat dari berapa persen mahasiswa yang telah mencapai skor $70 \%$ atau skor yang termasuk kategori nilai B (Pedoman Akademik UM, 2012). Selain itu, dalam penelitian ini dilihat juga meningkatan skor perolehan mahasiswa di setiap siklus yang dihitung dengan: Perolehan (gain score $)=($ skor posttest skor pretest) 
HASIL DAN PEMBAHASAN

Prestasi Belajar Mahasiswa Bilingual dalam Matakuliah Kimia Dasar I

Pada siklus I, mahasiswa belajar materi "Measurement" yang terdiri dari subtopik: SI unit, metric system, density, uncertainty in measurement, significant figures, accuracy and precision. Pembelajaran pada materi tersebut dilakukan selama empat (4) kali tatap muka (@ 100 menit). Pada siklus II, mahasiswa belajar materi "Matter and its changes" yang terdiri dari subtopik: particulate nature of matter, physical state of matter, classification of matter, properties of matter, physical and chemical changes. Pembelajaran pada siklus II dilakukan selama enam (6) kali pertemuan (@ 100 menit).
Sedangkan pada siklus III, mahasiswa belajar materi "nomenclature inorganic chemistry and quantitative composition of compound" yang terdiri dari subtopik: common and systematic names, elements and ions, writing formulas of ionic compound, naming binary compounds, naming compounds containing polyatomic ions, mole, molar mass of compounds, percent composition of compounds, empirical versus molecular formula, calculating the molecular formula from empirical formula. Pembelajaran berlangsung selama lima (5) kali tatap muka (@ 100 menit). Data prestasi belajar mahasiswa dapat dilihat pada Tabel 1 dan peningkatan prestasi belajar juga dapat dilihat pada Grafik 1 berikut.

Tabel 1. Prestasi Belajar Mahasiwa Bilingual dalam Siklus I, II dan III

\begin{tabular}{lccc}
\hline & SIKLUS I & SIKLUS II & SIKLUS III \\
\hline Skor rata-rata pretest & 60 & 66 & 71 \\
Skor rata-rata Posttest & 60 & 74 & 86 \\
Gain score & -1 & 8 & 15 \\
$\Sigma$ ketuntasan $70 \%$ & 5 orang (pretest) & 10 orang (pretest) & 11 orang (pretest) \\
& 3 orang (posttest) & 15 orang (posttest) & 22 orang (posttest) \\
Persen Ketuntasan 70\% & $22 \%$ (pretest) & $43 \%$ (pretest) & $48 \%$ (pretest) \\
& $13 \%$ (posttest) & $65 \%$ (posttest) & $96 \%$ posttest) \\
\hline
\end{tabular}

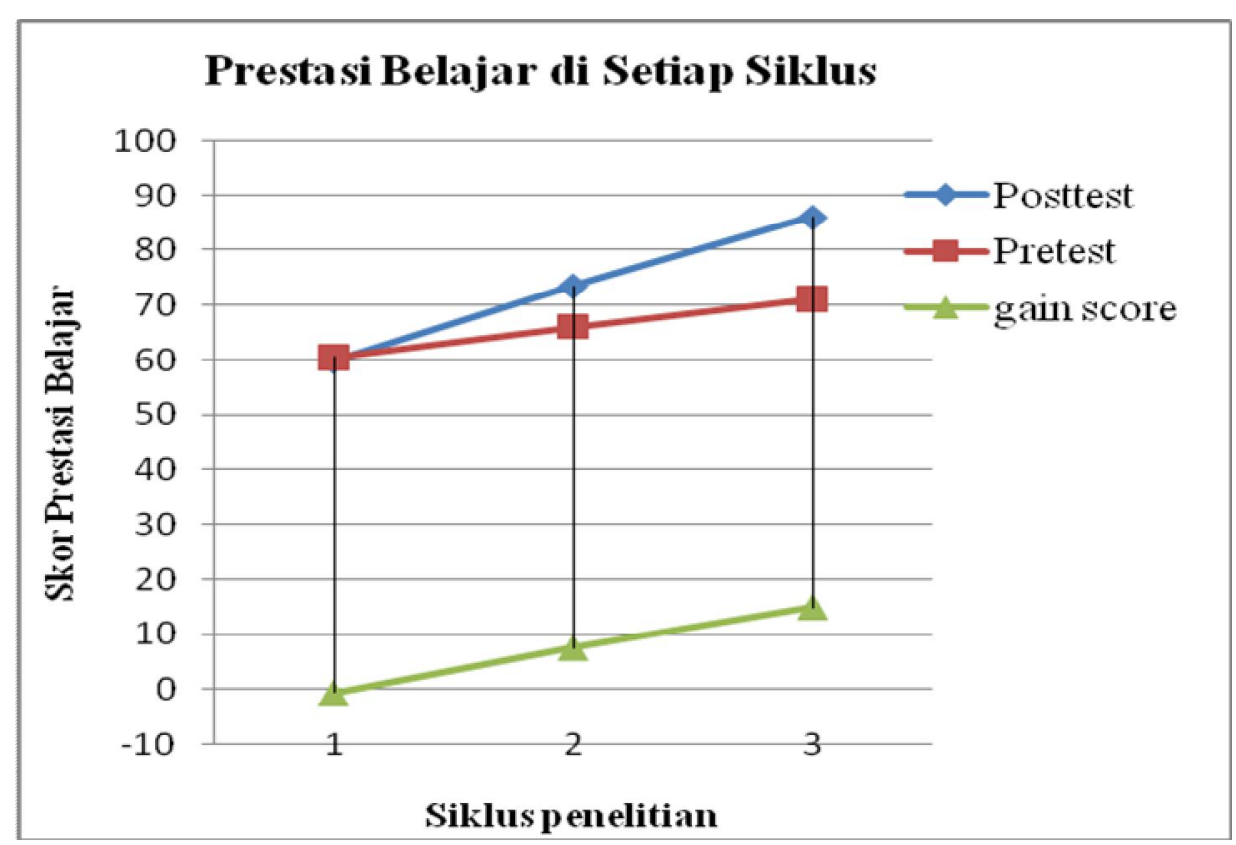

Grafik 1. Gain Score, Pretest dan Posttest Mahasiswa pada Siklus I, II \& III 
Terlihat bahwa rata-rata skor posttest mahasiswa pada siklus penelitian I tidak berbeda dengan rata-rata pretest. Hal ini berarti bahwa mahasiswa tidak memperoleh masukan dari kegiatan pembelajaran yang telah dilakukan. Bahkan, jika ditinjau dari rata-rata skor perolehan (gain score) mahasiswa nilainya -1 . Jumlah mahasiswa yang memperoleh skor $70 \%$ mengalami penurunan untuk posttest dibandingkan pretest sebesar 9\%. Ketika mahasiswa ditanya mengapa nilai posttest mereka lebih jelek dibandingkan nilai pretest, sebagian besar mahasiswa menjawab bahwa mereka lebih mempersiapkan pretest untuk materi siklus II dan kurang mempelajari materi yang sudah dipelajari untuk posttest materi dalam siklus I. Hal ini terjadi karena pelaksanaan pretest untuk materi siklus II bersamaan waktunya dengan pelaksanaan posttest untuk materi siklus I. Oleh karena itu, kelemahan ini diperbaiki pada siklus II dan III yaitu pelaksanaan pretest materi baru tidak bersamaan waktunya dengan pelaksanaan posttest materi sebelumnya.

Pada siklus II, prestasi belajar mahasiswa rata-rata antara pretest dan posttest sudah menunjukkan peningkatan yang signifikan dibandingkan dengan siklus I, yaitu rata-rata posttest 74, meningkat 8 poin dibandingkan dengan rata-rata skor pretestnya. Mahasiswa yang mendapatkan skor $70 \%$ juga mengalami peningkatan dalam siklus kedua yaitu 15 orang (65\%). Pada siklus III, rata-rata skor mahasiswa antara pretest dan posttest sudah menunjukkan peningkatan yang signifikan dibandingkan dengan siklus II, yaitu rata-rata posttest 86 , meningkat 15 poin dibandingkan dengan rata-rata skor pretestnya. Mahasiswa yang mendapatkan skor $70 \%$ juga mengalami peningkatan dalam siklus III yaitu 22 orang (96\%).

Berdasarkan hasil penelitian dalam ketiga siklus tersebut dapat disimpulkan bahwa penerapan TBL dapat meningkatkan prestasi belajar mahasiswa bilingual dalam perkuliahan Kimia Dasar I. Skor pretest, posttest, dan gain score mahasiswa mengalami peningkatan yang cukup berarti. Hal ini menunjukkan bahwa mahasiswa semakin siap menerima materi baru dan dapat belajar lebih banyak melalui proses pembelajar- an TBL. Meningkatnya prestasi belajar mahasiswa bilingual ini sejalan dengan penelitian yang dilakukan oleh Tan, dkk (2011) pada mahasiswa jurusan kesehatan tahun ketiga di National Neuroscience Institute, Singapura. Penelitian ini juga sejalan dengan penelitian yang dilakukan oleh Carmichael (2009) pada mahasiswa Jurusan Biologi yang sedang mengambil mata kuliah biologi umum. Hasil penelitian Carmichael menunjukkan bahwa TBL bukan hanya efektif untuk meningkatkan prestasi belajar dan kinerja mahasiswa tetapi juga lebih membuat kelas hidup dan mahasiswa lebih aktif dalam diskusi. Hasil penelitian ini sejalan dengan penelitian yang dilakukan oleh Kühne-Eversmann dkk (2008) pada mahasiswa Jurusan Kesehatan di Jerman.

\section{Kualitas Proses Pembelajaran TBL pada Matakuliah Kimia Dasar I}

Kualitas proses pembelajaran dengan TBL diamati melalui: (1) keaktifan mahasiswa dalam mengajukan pertanyaan, menjawab dan menanggapi respon dalam diskusi kelas; (2) ketepatan waktu dalam melakukan diskusi kelompok; (3) interaksi mahasiswa dalam kegiatan kelompok; dan (4) kemampuan mahasiswa dalam menjelaskan pemecahan masalah dalam bahasa Inggris. Hasil penelitian dalam aspek kualitas proses pembelajaran pada siklus I, II, dan III dinyatakan dalam Tabel 2.

Hasil penelitian dalam siklus I menunjukkan bahwa sebagian besar mahasiswa sudah mengikuti pembelajaran dengan baik dan telah menunjukkan partisipasinya dalam kegiatan diskusi kelompok dan diskusi kelas, namun belum sering mengajukan pertanyaan, menjawab, atau menanggapi respon dalam diskusi kelas. Ada dua mahasiswa sangat aktif dalam bertanya dan berdiskusi di dalam kelompok masing-masing maupun di kelas. Dalam kelas tersebut terjadi dominasi dalam kelas sehingga pertanyaan dan tanggapan didominasi oleh kedua mahasiswa tersebut. Namun, dalam siklus II dan III dominasi oleh mahasiswa tidak terjadi lagi karena semakin banyak yang aktif dalam mengajukan pertanyaan dan menanggapi respon dalam diskusi kelas. 
Tabel 2. Capaian Proses Pembelajaran Siklus I, Siklus II dan Siklus III

\begin{tabular}{lccc}
\hline \multicolumn{1}{c}{ Aspek } & $\begin{array}{c}\text { Capaian Siklus I } \\
(\%)(\text { orang })\end{array}$ & $\begin{array}{c}\text { Capaian Siklus } \\
\text { II }(\%)(\text { orang })\end{array}$ & $\begin{array}{c}\text { Capaian } \\
\text { siklus III }(\%)(\text { orang })\end{array}$ \\
\hline $\begin{array}{l}\text { Keaktifan mahasiswa mengajukan pertanyaan, } \\
\text { menjawab atau menanggapi respon }\end{array}$ & $9(2)$ & $52(12)$ & $74(17)$ \\
Ketepatan waktu menyelesaikan tugas kelompok & $33(2 *)$ & $67(4 *)$ & $83\left(5^{*}\right)$ \\
Interaksi mahasiswa dalam kelompok & $22(5)$ & $48(11)$ & $80(18)$ \\
Kemampuan mahasiswa menjelaskan & & $40(9)$ & $60(14)$ \\
pemecahan masalah dalam bahasa Inggris & $22(5)$ & & \\
\hline
\end{tabular}

*kelompok

Dalam aspek ketepatan waktu dalam menyelesaikan tugas, mulai dari siklus I ke siklus III kelompok yang dapat menyelesaikan tugas sesuai dengan waktu yang ditentukan mengalami peningkatan. Ditinjau dari aspek interaksi mahasiswa, nampak dalam dari Tabel 2 bahwa Interaksi mahasiswa dalam kelompok semakin meningkat dan diskusi kelompok semakin hidup. Selain itu, semakin banyak mahasiswa yang menjelaskan pemecahan masalah dalam bahasa Inggris walaupun sebenarnya mereka boleh menggunakan bahasa Indonesia.

Perbaikan-perbaikan yang telah dilakukan di siklus II dan III berdasarkan refleksi pada pelaksanaan siklus I atau II adalah (1) upaya untuk lebih memotivasi mahasiswa dalam berdiskusi dengan menggunakan bahasa Inggris dan mendorong mereka untuk mengajukan pertanyaan berkaitan dengan cara membaca handouts dan juga konsep-konsep yang dirasa sulit oleh mereka, (2) handouts dalam bahasa Inggris dipilih yang paling sederhana dalam penggunaan kosa katanya sehingga mudah dipahami, (3) lebih banyak memberikan penekanan konsep dengan cara menjelaskannya dalam bahasa Inggris.

Dari hasil penelitian yang diperoleh dalam aspek kualitas proses pembelajaran dengan TBL, disimpulkan bahwa strategi TBL dapat meningkatkan kualitas proses pembelajaran Kimia Dasar I. Kualitas proses yang difokuskan adalah keaktifan mahasiswa di kelas dalam mengajukan pertanyaan dan menanggapi respon dalam diskusi kelas, ketepatan waktu dalam menyelesaikan tugas kelompok, interaksi mahasiswa dalam kelompok, dan kemampuan mahasiswa dalam menjelaskan pemecahan masalah dalam bahasa Inggris di kelas maupun dalam kelompok. Peningkatan kualitas proses pembelajaran dengan TBL ditemukan juga pada Penelitian yang dilakukan oleh Carmichael (2009).

\section{Persepsi Siswa tentang Strategi Pembelajar- an Team-Based Learning}

Dari hasil penyebaran angket persepsi mahasiswa terhadap pembelajaran TBL diperoleh data untuk tiap-tiap pertanyaan sebagai berikut.

- Apakah Saudara menyukai strategi pembelajaran "Team-Based Learning" yang Saudara alami dalam matakuliah Kimia Dasar I ini? Sebanyak 17 mahasiswa (74\%) sangat menyukai strategi $T B L, 5$ orang mahasiswa (22\%) cukup menyukai dan 1 orang (4\%) kurang menyukai $T B L$. Berikut contoh alasan yang mereka kemukakan.

Respon sangat menyukai TBL:

- "Dengan proses pembelajaran ini saya dapat belajar lebih efektif karena jika saya kurang paham materi saya bisa bertanya terlebih dahulu pada kelompok saya"

- "Karena menurut saya model berkelompok ini berbeda dengan kelompok pada umumnya. Dalam kelompok ini, semua anggota sudah tahu apa yang akan didiskusikan (hasil pretest yang sudah dikerjakan) sehingga lebih hidup dan bisa bertukar pikiran"

\section{Respon cukup menyukai TBL:}

- "karena dapat menambah wawasan dari pemecahan suatu masalah dalam forum diskusi” 
- "Karena bisa saling share jawaban dengan teman sekelompok lalu menyimpulkan jawaban mana yang paling tepat"

Respon kurang menyukai TBL:

- "Karena sifat belajar saya adalah cenderung individual dan lebih suka diajar"

- Apakah Saudara merasa memiliki persiapan dalam mengikuti setiap perkuliahan Kimia Dasar I? Sebanyak 13 mahasiswa (57\%) mengatakan cukup siap dalam mengikuti perkuliahan, 9 mahasiswa (39\%) mengatakan kurang siap dan hanya 1 orang mahasiswa (4\%) mengatakan sangat siap. Berikut ini beberapa contoh respon mahasiswa.

Respon sangat siap mengikuti pembelajaran:

- "Karena dengan persiapan yang mantap (literatur ada) kita menjadi bersemangat dalam pembelajaran..."

Respon cukup siap dalam mengikuti pembelajaran:

- "Karena setiap awal pertemuan diadakan pretest, sehingga mau tidak mau sebelumnya sudah belajar materi yang akan dibahas dan hasilnya cukup membantu dalam peyerapan materi yang diajarkan"

Respon kurang siap dalam mengikuti pembelajaran:

- "Karena sebelum dimulainya perkuliahan, sehari sebelumnya sudah diberi materi yang akan diajarkan esok harinya

- Apakah pemahaman Saudara tentang konsep-konsep kimia meningkat setelah mengikuti Kegiatan Pembelajaran Kimia Dasar I? Sebanyak 9 mahasiswa (39\%) mengatakan bahwa pemahamannya sangat meningkat setelah pembelajaran dengan strategi TBL, 13 mahasiswa (57\%) mengatakan cukup meningkat dan 1 orang menyatakan bahwa pengetahuannya kurang meningkat (4\%). Berikut ini contoh respon mahasiswa:

Respon pemahaman sangat meningkat:

- "Karena dulu waktu SMA saya diajarkan kimia secara umum, namun pada pem- belajaran Kimia Dasar I lebih mendetail tentang dasar-dasar kimia"

- Karena di mata kuliah ini dijelaskan lebih detail sehingga pemahaman yang pernah saya dapatkan di SMA menjadi lebih jelas sekarang"

Respon pemehaman cukup meningkat:

- "banyak konsep-konsep kimia baru dimengerti, dulu waktu di SMA belum paham"

- "Dengan adanya pretest-posttest membuat mahasiswa mau membaca dan konsep "team" digunakan untuk mengevaluasi sekaligus untuk memahami materi”

Respon pemehaman kurang meningkat:

- Karena faktor bahasa membuat saya kurang memahami secara utuh tentang mata kuliah ini. Terkadang ada kata atau kalimat yang benar-benar sulit dipahami"

- Apakah kegiatan diskusi dalam kelompok membantu Saudara dalam memahami konsep-konsep kimia dalam Matakuliah Kimia Dasar I? Sebanyak 10 mahasiswa (44\%) mengatakan bahwa diskusi dalam kelompok sangat membantu dalam memahami konsep, 12 mahasiswa (52\%) mengatakan diskusi kelompok cukup membantu dan hanya 1 orang (4\%) mengatakan kurang membantu pemahaman konsep. Berikut beberapa respon mahasiswa.

Respon diskusi kelompok sangat membantu pemahaman:

- "Karena anggota kelompok saya tidak pernah pelit dalam membagi ilmu yang mereka punya sehingga saya merasa memiliki banyak guru yang membimbing saya"

- "Teman-teman saya dalam satu kelompok sangat kompak kalau satu orang tidak mengerti yang lainnya mengajari”

Respon diskusi kelompok cukup membantu pemahaman:

- "Karena setiap anggota dari kelompok saya memiliki pendapat-pendapat yang berbeda tentang suatu masalah. Mereka mendapatkan jawaban dari masalah 
tersebut dari analisa dan sumber yang berbeda sehingga itu sangat membantu untuk menambah wawasan dalam memecahkan masalah"

- "Teman dalam satu kelompok dapat menyadarkan saya konsep-konsep penting yang mungkin saya lewati (tidak saya sadari) saat membaca materi"

Respon diskusi kelompok kurang membantu pemahaman:

- "Walaupun sedikit membantu dalam memecahkan suatu masalah tetap saja kurang membantu karena konsep belajar saya lebih individual dan lebih senang dijelaskan dosen"

- Apakah diskusi kelas dan penjelasan dosen membantu Saudara dalam memahami konsep-konsep kimia dalam Kimia Dasar I? Sebanyak 17 mahasiswa (74\%) menyatakan bahwa diskusi kelas dan penjelasan dosen sangat membantu mereka dalam memahami konsep. Sebanyak 6 mahasiswa (26\%) menyatakan cukup membantu. Berikut contoh pernyataan mereka.

\section{Respon sangat membantu:}

- "Dalam diskusi kita menyelesaikan permasalahan bersama terlebih dahulu, kemudian dosen menjelaskan, sehingga belajar lebih efektif dan sangat membantu dalam pemahaman konsep"

- "Karena dalam berdiskusi dan penjelasan dosen kita bisa memahami dengan mantap materi tersebut selain itu dalam penjelasan dosen yang sangat membantu apabila konsep dasar dijelaskan dalam bahasa Indonesia"

\section{Respon cukup membantu:}

- "Karena dosen menjelaskan perchapter dan 'step by step' tidak terlalu cepat dan tidak terlalu lambat"

- Bagaimanakah sebaiknya materi pelajaran Kimia Dasar I SBI disampaikan di kelas? Sebagian besar mahasiswa menyukai pembelajaran dilaksanakan secara bilingual dengan rincian:
- Sebanyak 11 mahasiswa (48\%) menyukai materi disampaikan secara bilingual, yaitu masing-masing $50 \%$ baik dalam bahasa Inggris dan bahasa Indonesia untuk verbal (diskusi dan penjelasan dosen) maupun tulisan (hand-outs \& power point).

- Sebanyak 10 mahasiswa (43\%) menyukai materi disampaikan secara bilingual, yaitu masing-masing $50 \%$ baik dalam bahasa Indonesia dan bahasa Inggris untuk verbal (diskusi dan penjelasan dosen) dan $100 \%$ dalam bahasa Inggris untuk tulisan (hand-outs \& powerpoint)

- Seorang mahasiswa lebih menyukai $100 \%$ dalam bahasa Inggris baik verbal maupun tulisan dan seorang mahasiswa lainnya memberi masukan yaitu $100 \%$ dalam bahasa Inggris verbal (diskusi \& penjelasan dosen) maupun handouts, serta dilampirkan terjemahan handouts dalam bahasa Indonesia.

Secara umum mahasiswa program bilingual yang menempuh matakuliah Kimia Dasar I memiliki persepsi positif terhadap pembelajaran TBL. Hampir semua mahasiswa menyukai strategi pembelajaran TBL. Mereka yakin bahwa pemahaman mereka tentang materi yang sedang dipelajari semakin meningkat dan hal ini juga terbukti dari rata-rata skor posttest mereka yang meningkat. Selain itu, mereka merasa semakin siap dalam menerima materi perkuliahan baru, hal ini juga ditunjukkan oleh skor pretest mereka yang semakin meningkat. Mereka beranggapan bahwa diskusi dalam kelompok, diskusi kelas, dan penjelasan dosen sangat membantu mereka dalam memahami materi kimia. Meningkatnya rasa percaya diri (selfefficacy) mahasiswa ini sejalan dengan penelitian yang dilakukan oleh Macke \& Tapp (2012), Thanongsak dkk (2011) dan Reinig (2011).

Dalam hal penyampaian materi pembelajaran, sebagian besar mahasiswa menyukai jika pembelajaran dilaksanakan secara bilingual yaitu $50 \%$ disampaikan dalam bahasa Inggris dan selebihnya bahasa Indonesia, sedangkan handouts dan powerpoint disampaikan $100 \%$ atau $50 \%$ dalam bahasa Inggris. 
Dari respon yang disampaikan mahasiswa, ternyata kesulitan mahasiswa yang paling utama dalam kimia dasar bilingual adalah banyak kosa kata yang belum mereka pahami dengan baik sehingga mereka merasa agak kesulitan dalam membaca handouts. Namun, dengan adanya team yang memiliki kemampuan akademik dan kemampuan bahasa Inggris yang heterogen, mereka bisa yang saling membantu dan mereka pada akhirnya bisa saling belajar tentang materi yang sedang mereka pelajari. Meningkatnya partisipasi mahasiswa dalam pembelajaran TBL dapat menciptakan dan mendorong perkembangan kecerdasan emosional (Clarke, 2010:119). Pada dasarnya semua topik dalam Kimia Dasar I sudah mereka pelajarari di SMA, namun dalam matakuliah Kimia Dasar I penekanan pada konsep-konsep penting yang kurang mendapat perhatian di SMA dipelajari lagi sehingga dari sisi materi bukan hal yang sama sekali baru bagi mereka.

\section{PENUTUP}

\section{Kesimpulan}

- Penerapan strategi pembelajaran TBL dapat meningkatkan prestasi belajar Kimia Dasar I pada mahasiswa Bilingual semester I tahun 2012/2013. Hal ini ditunjukkan dengan meningkatnya skor posttest dan gain score dari siklus I sampai siklus III. Selain itu, mahasiswa yang mendapatkan skor 70 atau nilai B juga semakin meningkat yang pada siklus III hampir $100 \%$ mahasiswa mendapatkan nilai B untuk skor posttest.

- Penerapan strategi TBL dapat meningkatkan kualitas proses pembelajaran Kimia Dasar I pada mahasiswa bilingual semester I tahun 2012/2013. Hal ini ditunjukkan dengan semakin meningkatnya: keaktifan mahasiswa di kelas dalam mengajukan pertanyaan dan menanggapi respon, ketepatan waktu dalam menyelesaikan tugas kelompok, interaksi mahasiswa dalam diskusi kelompok, dan kemampuan mahasiswa dalam menjelaskan pemecahan masalah dalam bahasa Inggris di kelas maupun dalam kelompok.

- Mahasiswa bilingual yang diajar Kimia Dasar I semester 1 tahun 2012/2013 memiliki persepsi yang positif terhadap strategi pembelajaran TBL. Hampir semua mahasiswa menyukai strategi pembelajaran TBL. Mereka yakin bahwa pemahaman mereka tentang materi yang sedang dipelajari semakin meningkat, semakin siap dalam mengikuti perkuliahan, dan mereka yakin bahwa diskusi dalam kelompok, diskusi kelas dan penjelasan dosen membantu mereka dalam memahami materi kimia. Selain itu, sebagian besar mahasiswa menyukai jika pembelajaran dilaksanakan secara bilingual yaitu $50 \%$ disampaikan dalam bahasa Inggris dan selebihnya bahasa Indonesia, sedangkan handouts dan powerpoint disampaikan $100 \%$ atau 50\% dalam bahasa Inggris.

\section{Implikasi}

Strategi pembelajaran TBL merupakan strategi alternatif yang dapat diterapkan dalam pembelajaran Kimia Dasar atau matakuliah lainnya di perguruan tinggi. Strategi ini terbukti dapat mendorong siswa menjadi lebih aktif berpartisipasi dalam pembelajaran yang pada gilirannya dapat meningkatkan prestasi belajar mereka. Jika dosen ingin mengadopsi strategi ini yang perlu dipersiapkan adalah perencanaan waktu harus benar-benar baik, pretest dan posttest harus dirancang dengan sebaik-baiknya sehingga jika dibandingkan dengan pembelajaran dengan ceramah, pembelajaran dengan TBL tidak memerlukan banyak waktu yang lebih panjang dan pembelajaran lebih berpusat pada mahasiswa.

\section{UCAPAN TERIMA KASIH}

Penulis mengucapkan terima kasih dengan terselenggarakannya penelitian ini atas bantuan dana dari Program Hibah PGMIPA-BI FMIPA UM tahun anggaran 2012/2013.

\section{DAFTAR PUSTAKA}

Carmichael, J. 2009. “Team-Based Learning Enhances Performance in Introductory Biology", dalam Journal of College Science Teaching, 38(4), hlm. 54-61.

Clarke, N.2010. "Developing Emotional Intelligence Abilities Through Team-Based Le- 
arning", dalam Human Resource Development Quarterly, 21(2), hlm.119-138.

Gabel, D. L. 1999.” Improving Teaching And Learning Through Chemistry Education Research: A Lock to The Future", dalam Journal of Chemical Education, 76(4), hlm. 548-554.

Johnson, D., \& Johnson, R. 1986. “Action Research: Cooperative Learning in The Science Classroom", dalam Science and Children, 24, hlm. 31-32.

Johnstone, A.H., 2000. "Teaching of Chemistry-Logical or psychological?" Chemistry Education: Research and Practice in Europe, 1(1), hlm 9-15.

Kemmis, S. \& McTaggart, R. 1988. The Action Research Planner. Third Edition. Victoria: Deakin University Press.

Kühne-Eversmann, L., Eversmann, T., \& Fischer, M. R. 2008. "Team- And Case-Based Learning to Activate Participants and Enhance Knowledge: An Evaluation of Seminars in Germany", dalam Journal of Continuing Education in The Health Professions, 28(3), hlm 165-171.

Letassy, N. A., Fugate, S.E., Medina, M.S., Stroup, J.S., \&Britton, M.L. 2008. "Instructional Design and Assessment: Using Team-Based Learning in An Endocrine Module Taught Across Two Campuses", dalam American Journal of Pharmaceutical Education, 72 (5), hlm. 1-6.

Macke, C. \& Tapp, K. 2012. "Teaching Research to MSW Students: Effectiveness of The Team-Based Learning Pedagogy", dalam Journal of Teaching in Social Work, 32(2), hlm.148-160.

Michaelsen, L. K. \& Sweet, M. 2008. "The Essential Elements of Team-Based Learning", New Directions for Teaching and Learning, 116, hlm. 7-27.

Reinig, B. A., Horowitz, I \& Whittenburg, G. E. 2011. "The Effect of Team-Based
Learning on Student Attitudes and Satisfaction", dalam Decision Sciences Journal of Innovative Education, 9(1), hlm. 27-47.

Slavin, R. 1995. Cooperative Learning: Theory, Research, and Practice (2nd Ed.). Boston: Allyn \& Bacon.

Stieff, M., \& Wilensky, U. 2003. "Connected Chemistry-Incorporating Interactive Simulations into The Chemistry Classroom", dalam Journal of Science Edu-cation \& Technology, 12(3), hlm.285-302.

Sweet, M \& Pelton-Sweet, M. L. 2008. "The Social Foundation of Team-Based Learning: Students Accountable to Students", dalam New directions for teaching and learning, 116, hlm.29-40.

Sweet, M \&. Michaelsen, L. K. 2007. "How Group Dynamics Research Can Inform The Theory and Practice of Postsecondary Small Group Learning", dalam Education Psychology Review, 19,hlm. 3147.

Tan, N. C.K, Kandiah, N., Chan, Y.H., Umapathi, T., Lee, S.H. and Tan, K. 2011. A controlled study of team-based learning for undergraduate clinical neurology education. BMC Medical Education, 11 (91). Hlm1-8. Http://www.biomedcentral.com/ 1472-6920/11/91. Diunduh tanggal 3 Oktober 2012.

Thanongsak, S., Kalayanee, J., \& Raveewan, S. 2011. "Team-Based Learning: Perceptions of Instructors and Students in Thai Universities", dalam Journal of College Teaching \& Learning, 8 (11), hlm. 39-50.

Thompson, B.M., Schneider, V. F., Haidet, P., Levine, R.E., McMahon, K. K., Perkowski, L. C., \& Richards, B. F. 2007. "Team-Based Learning at Ten Medical Schools: Two Years Later", dalam Medical Education, 41, hlm.250-257.

Turner, M. 2001. Groups at work: Theory and research. Mahwah, NJ: Erlbaum. 